\title{
Improving Students' Mathematical Problem Solving Ability and Self-Efficacy through Guided Discovery Learning in Local Culture Context
}

\author{
Rustam E. Simamora ${ }^{1 *}$, Sahat Saragih ${ }^{1}$, Hasratuddin $^{1}$ \\ ${ }^{1}$ State University of Medan, INDONESIA \\ *CORRESPONDENCE: $\square$ erustam@yahoo.co.id
}

\begin{abstract}
Qualified learning materials is needed in the efforts to improve the quality of teaching-learning mathematics. Qualified learning materials can be obtained through development research. Learning materials in this study were learning materials that were developed based on guided discovery learning model. The learning materials was also developed by integrating local culture into a guided learning model. The local culture in this study was adapted to the local culture of the students, namely the Batak Toba. Learning materials in this study were developed using the development model of Thiagarajan et al. (1974). The result of second trial showed that learning materials based guided discovery learning with Batak Toba context improved students' mathematical problem solving ability and self-efficacy significantly. Based on the results of the study, it was suggested that mathematics teachers make an effort qualified learning materials and integrate local culture in mathematics learning.
\end{abstract}

Keywords: ethnomathematics, guided discovery, problem solving ability, self-efficacy

\section{INTRODUCTION}

The vision of Indonesian mathematics education states that mathematics education is devoted to understanding mathematical concepts and ideas which are then applied in routine and non-routine problem solving through reasoning, communication, and connection development inside mathematics and outside mathematics itself (Saragih et al., 2017). Students are expected to be able to use mathematics and mathematical thinking, both in daily life learn and also learning science subjects (Saragih \& Napitupulu, 2015). The results of the data analysis of PISA 2013 by Scherer \& Beckmann (2014) stated that mathematical and scientific competencies significantly contribute to problem solving throughout the country.

Phonapichat et al. (2014) stated that the main purpose of teaching mathematics is to enable students to solve problems in daily life. The mathematical problem solving ability itself is not only a goal in mathematics learning, but also something that is very meaningful in daily life (Pinter, 2012), and in the world of work; being a problem-solver can provide benefits or benefits (NCTM, 2000). Therefore learning should be developed to educate students to be able to realize and solve the problems that they face (Balım, 2009).

\section{Mathematical Problem and Mathematical Problem Solving Ability}

A situation is called a problem when there is an awareness that the importance of carrying out an action but cannot immediately fulfill it (Ernest, 1991; Giganti, 2007; Szetela \& Nicol, 1992). In the context of formal education, on mathematics subjects, students will also face problems. Problems in mathematics are present

Article History: Received 5 June $2018 \bullet$ Revised 30 September $2018 \bullet$ Accepted 12 October 2018

(C) 2019 by the authors; licensee Modestum Ltd., UK. Open Access terms of the Creative Commons Attribution 4.0 International License (http://creativecommons.org/licenses/by/4.0/) apply. The license permits unrestricted use, distribution, and reproduction in any medium, on the condition that users give exact credit to the original author(s) and the source, provide a link to the Creative Commons license, and indicate if they made any changes. 
in the form of questions. These problems can be sourced from within mathematics itself, and can also be sourced from real life (Foshay \& Kirkley, 2003) involving facts and cultural environments that can be modeled into mathematics. If student is ready to give a solution strategy to a mathematical problem, then the question is no longer a problem, but an exercise (Schoenfeld, 1987).

Vygotsky believed that learning occurs when students work or learn to handle complex tasks or problems that are still within the cognitive reach of students or those tasks are in the Zone of Proximal Development (ZPD) (Taylor, 1993). Vygotsky stated that ZPD is between the actual level of development as determined through independent problem solving and the level of potential development as determined through problem solving under the guidance of adults or working with more capable partners. If a problem can be resolved independently (without the help of another person or teacher) by the student, then the student is already in the Actual Ability Level (AAL). However, if the problem can be solved by students in the presence of other people (teacher or role models or peers) who better understand the problem, then the student is already at his Potential Ability Level (PAL). If the teacher poses a problem to be solved by students, the problem should be between AAL and PAL or the problem is in the area of students' cognitive reach. So, mathematical problems can be interpreted as questions or mathematical questions originating from real life whose difficulties still lie in the reach of students' thinking but there are no algorithms or procedures that students can immediately apply.

Bahar and Maker (2015) stated that the concept of problem solving is referred to by scientists as a highlevel thinking process consisting of intellectual ability and major cognitive processes. To solve a problem, a problem solver can use the strategy or steps formulated by Polya (1973), that is, we must first understand the problem; we must see clearly what is requested. Second, we must see how things are connected, how the unknown is connected to data, to get ideas about solutions, to plan solutions. Third, we carry out the plan. Fourth, we looking back to the solutions that have been obtained, we review them again and discuss them.

Students' mathematical problem solving ability can be defined as students' ability to understand problems, plan problem solving strategies, carry out selected strategies of completion, and re-examine problem solving to subsequently make solutions in other ways or develop problem solving when students are dealing with mathematical problems ( Kuzle, 2013; OECD, 2004; Polya, 1973; Szetela \& Nicol, 1992).

Even though mathematics is a very important subject in formal education and is closely related to human life, mathematics is not a subject of interest to students. The mathematical problem solving ability of Indonesian students are still low (Nidya et al., 2015; Jerizon et al., 2018). Simamora et al. (2017) reported that the results of interviews with teachers stated that word problem in mathematics was very difficult for students. It was also found that many students did not like mathematics because mathematics was too difficult for these students. The same matter, the low mathematical problem solving ability of students, also reported Simamora et al. (2017) when making observations at SMA Negeri 1 Pagaran (senior high school). The results of interviews with teachers at the school stated that mathematics was a subject that was not in demand by most students. The results of the observations through the provision of diagnostic tests to students of class X6 SMA Negeri 1 Pagaran (10 th grade learners), with a test in the form of a description to describe students' ability to solve mathematical problems, obtain similar information; problem solving ability is very low. These reports show that the achievement of Indonesia's mathematical education vision is still far from expectations. The problem solving ability, as one aspect of the higher order thinking ability, is a very important ability. The low mathematical problem solving ability is an crucial problem to solved.

\section{Mathematical Self-Efficacy}

In mathematics learning, students' mental condition is an important aspect. The student's belief system (about itself about mathematics, about problem solving) determines student success in solving problems (Schoenfeld, 2013). Student self-efficacy, which is the student's confidence in his ability, influences students' mathematical problem solving ability. Students' mathematical self-efficacy is the students' belief in their level, generality, and strength of these students in various activities and contexts in learning mathematics (Bandura, 1994; Zimmerman, 2000). Self-efficacy belief influences life choices, motivation levels, function quality, resistance to difficulties and vulnerability to stress and depression (Bandura, 1994).

Many researches on student self-efficacy have been carried out. The study results that self-efficacy is closely related to mathematics learning achievement (Ayotola \& Adedeji, 2009; Liu \& Koirala, 2009; Motlagh et al., 2011). Skaalvik et al. (2015) stated that student motivation was strongly predicted by self-efficacy. So, the student's self-efficacy should be taken seriously by the teacher. Teachers must find ways to improve 
students' mathematical learning ability and must emphasize self-efficacy by designing appropriate learning (Ayotola \& Adedeji, 2009). The source of students' main beliefs to improve students' self-efficacy is: performance accomplishments/mastery experience; vicarious experience, verbal persuasion and emotional arousal (Bandura, 1994; Schunk \& Pajares, 2001; Zimmerman, 2000).

\section{GUIDED DISCOVERY LEARNING}

According to Bruner, discovery learning was a learning model that uses inquiry-based constructivist learning theory that occurs in problem solving situations where learners learn through existing knowledge and previous experience to find facts and relationships with new material being studied (Bruner, 1961; Learning Theories, 2017). Through discovery learning, the teacher provides opportunities for his students to become problem solvers, scientists, historians, or mathematicians (Kementerian Pendidikan dan Kebudayaan, 2014).

To anticipate misconceptions or incomplete or unorganized knowledge, discovery learning is developed by integrating guidance in learning activities. Furthermore, discovery learning with the existence of guidance is referred to as a guided discovery learning model. Guided discovery learning is still centered on students and the teacher acts as a guide. Guidance given by the teacher is limited, because if there are too many guidelines for discovery, then learning will be similar to direct learning, and thus learning loses its benefits (Yang et al., 2010). Learning that is promoted in guided discovery is to foster learners' ability in discovery, exploration, problem solving and independent thinking, and creation and discovery through creative learning. In guided discovery learning, students can actively and positively participate in learning and integrate and construct their own knowledge (Shieh \& Yu, 2016). Guided discovery learning is learning with the pattern of the scientific method to find problem solving by students in groups with steps starting from stimulation, problem statement/identification, data collection, data processing, verification, to drawing conclusions (Yerizon et al., 2018) .

Alfieri et al. (2011) conducted a comparative study between unassisted discovery learning, direct instruction/explicit learning, and guided discovery learning. The results of the study stated that the best results were found in students learning with guided learning. Furthermore, the results of Herdiana et al. (2017) report that guided discovery learning is effective for improving mathematical problem solving ability.

\section{Integrating Students' Local Culture in Learning}

Students enter secondary education with a large number of concepts that represent complex and natural thinking and reasoning ability, reflecting students' daily experiences (Haenen et al., 2003). Students' understanding of mathematical ideas can be built throughout the experience when students are actively involved in tasks and learning that are designed to deepen and connect students' knowledge (Kaiser, 2002). Meanwhile, culture can determine students' feelings for participation in class discussions, start questions, accept authority, remember facts, find innovative ways of understanding, and many other aspects of classroom education (Balamurugan, 2015).

The view of Neo-Vygotskian, Ylimaki (2010), stated that effective learning lied in activity, context, and culture as collaborative efforts in groups. Meanwhile, Dewey stated that cultural concepts cover a variety of human activities and practices needed to understand individual thoughts and actions (Miettinen, 2000). This shows that the cultural context of students should be a concern in learning. Students' cultural values that are relevant to education should be integrated into learning and used as the basis for developing learning. The cultural context not only plays an important role in humanity subjects, but also plays an important role in mathematics and science subjects. There is mathematical thinking behind the actions and discourses of many people and even behind all kinds of products that are different from human activities (d'Entremont, 2015; Palhares, 2012).

Cultural products in the form of artifacts, concrete objects as a result of human intelligence, or ancestral educated values or student environments where the culture is located can be used as inspiration in rediscovering mathematical concepts. In addition, learning based on culture provides space for students to maintain nobility and the opportunity to appreciate their culture. The connection between culture and mathematics itself has received serious attention and developed and led to widely accepted ideas called ethnomathematics. Ethnomatematics is mathematics that is practiced by cultural groups, such as urban and rural communities, groups of workers, professional classes, children who do not have a certain age group, 
indigenous peoples, and so many other groups identified by the same goals and traditions (d'Ambrosio, 2006a; d'Ambrosio, 2006b).

Program Ethnomathematics, the idea put forward by d'Ambrosio (2006a, 2006b), has the main goal of restoring the dignity of culture to every individual and family, urban or rural communities, larger sociocultural groups consisting of various languages and jargon, beliefs, knowledge, and values. Rosa and Orey (2016), said that this pedagogy aims to help students become aware of how people mathematically think mathematically in their own culture and use this awareness to learn about formal mathematics, and improve their ability to do mathematical in context in the future front. Students also come to value and appreciate their previous mathematical knowledge, which enables them to understand and experience these cultural activities from a mathematical point of view, thus enabling them to make connections between school mathematics and the real world.

The attention of scientists or researchers in learning with a student-centered approach based on local culture in the field of mathematics education has become more widespread in recent times. Among the development research by Saragih et al. (2017). The results of the study indicated that the development of a valid and effective learning model to achieve high-order mathematical thinking in junior high schools. Research in the field of mathematical education with the context of local culture was also carried out by Yusra and Saragih (2016). This study provided results that there was an increase in students' ability in mathematical communication after being given learning with the joyful-based learning approach in the context of Malay Culture. The research also provided results that utilize local culture in mathematical teaching both in making concept discoveries, and in solving mathematical problems, could improve higher mathematical thinking ability.

\section{Guided Discovery Learning in Context of the Batak Toba Culture Context}

In this study, the cultural context used was Batak Toba culture, because the setting of research was in high school in the Batak Toba culture environment. The integration of the local culture with the guided discovery learning model forms a learning model which is referred to as Guided Discovery Learning in Context of the Batak Toba Culture Context (GDL-BTCC). GDL-BTCC has some characteristics, i.e: learning with problem solving activities, investigating, discovery/reinvention, small group, student-centered, guidelines, and learning using a local cultural context, namely Batak Toba:

\section{Learning with problem solving activities}

Ernest (1991) stated that mathematics itself is a social institution, problem posing and problem solving. Freire (1985) said that true learning is learning that proposes human problems in relation to the world. According to Polya (1973), a mathematics teacher who only trained his students to solve routine problems or operations, he was the same as killing mathematical student interest, limiting their intellectual development and wasting their teaching time. But if he or she increased the curiosity of his students through problem solving from real life students to gain knowledge and help them solve problems with stimulus questions, then the teacher has given students a sense of belonging to mathematics, understanding, and independent thinking. In problem solving activities during learning the teacher basically serves as a "trainer" for students. Students are asked to "think" more, and create rather than "quote" material (Schoenfeld, 1980).

\section{Learning with investigating}

The teacher submits lessons to students as material for students' thinking and re-examines their previous thoughts when students express their own thoughts. Bell (1981) stated that inquiry in mathematics was a special form, with its own characteristic components abstract, representative, modeling, generalization, proving, and symbolizing.

\section{Learning with discovery}

Polya stated that good education was education that provided opportunities for students to find things, which in this case are mathematical concepts by themselves (Schoenfeld, 1987). The concepts in mathematics are not given directly by the teacher to students. Students must be involved in the process of rediscovering the concept. Students are required to create ideas, look for relationships to form concepts. In students actively involved in the discovery of various concepts and principles through problem solving or the results of abstraction of various cultural objects. 


\section{Learning with small group}

The mechanism underlying high level mental work is a copy of social interaction (Confrey, 1995; Taylor, 1993). Schoenfeld (2013) said that ideas formed by individuals was often built and refined in collaboration with others. This implies that all cognitive, even high-level work in humans, starts from the culture and that means, students should learn through interaction with adults and more capable peers. Vygotsky stated that, in the implementation of learning required the organization of students in the classroom (Ormrod, 1995). Teachers need to implement learning strategies that allow students to interact with their friends.

\section{Learning with student centered}

In discovery learning, students are encouraged to learn on their own independently. Students are actively involved in the discovery of various concepts and principles through problem solving or the results of abstraction of various cultural objects. Concepts and rules in mathematics can be mastered in full by students, when students are actively involved in thinking about, discovering, and reconstructing the mathematical knowledge that is being studied (Ernest, 1991; Wheeler 1970). The teacher encourages and motivates students to gain experience by doing activities that allow students to discover mathematical concepts and principles for themselves. This learning arouses curiosity and fosters motivation in students to work until they find the answer. Students learn to solve problems independently with thinking skills because they have to analyze and manipulate information.

\section{Learning with guidelines}

In the guided discovery learning model, the teacher acts as a guide. This guidance is needed to anticipate negative things such as: cognitive overload, potential misunderstandings, and teacher's difficulties to detect problems and misunderstandings. Alfieri et al. (2011) stated that discovery learning without assistance has not benefit students, while feedback, examples of (success) work, scaffolding, and teacher explanations such as reinforcement will be beneficial to student learning achievement. Opportunities for constructive learning may not arise when students are left without help. The guided activity of the teacher has a scaffolding to help students. The activities given by the teacher require students to explain their own ideas and ensure that these ideas are accurate by providing timely feedback by the teacher. The activities that provided by the teacher provide examples of work on tasks that have been successful.

According to Ormrod (1995) scaffolding was the provision of assistance (support) that could support students more competent in their efforts to do a task/problem around the area of cognitive reach. Scaffolding can be in the form of simplifying tasks, giving limited instructions on what students should do, giving a model of procedure for completing tasks, showing students what they have done well, notifying students of mistakes in the process of problem solving, and maintaining frustration students are still at a level they can still bear. Giving guidance gradually must be reduced along with the more proficient students complete the tasks.

According to Evans and Swan (2014), students' ability can be developed by comparing alternative problem solving strategies in mathematics. This can be done by giving students the opportunity to simulate "sample student work" (examples of student work) to be discussed and criticized after they themselves have solved the problem. This approach potentially develops metacognitive actions in which students reflect their own planning decisions and actions during mathematical problem solving.

\section{Learning with Batak Toba Culture Context}

In the previous section, it was discussed the important role and cultural linkages with mathematics learning. In this study, cultural products integrated in learning are cultural products in the form of artifacts, such as "ruma Batak" (Batak Toba traditional houses) and "simin" (monuments/tombs); cultural products in the form of ancestral upbringing; and using student cultural environment settings such as rice fields, gardens, hills, Toba Lake. Examples of ancestral upbringing values that can be integrated into learning are: "Ndang tartuhuk sahalak pandindingan". The quotation states that heavy burden should be borne together. When learning with a problem solving approach, students should be taught in groups because the cognitive burden in problem solving is quite heavy.

\section{LEARNING MATERIALS}

Learning materials are essential and significant materials needed in teaching and learning activities in schools to improve teacher efficiency and improve student learning achievement (Nesari \& Heidari, 2014; 
Olayanki, 2016). Learning materials are a number of materials, tools, media, instructions, and guidelines that students and teachers will use to conduct learning activities (Nasution \& Sinaga, 2017; Trianto, 2013).

To carry out mathematics learning with a guided discovery model, learning materials are needed that are in accordance with the model and according to the local cultural context of the students. Therefore, it is necessary to develop a qualified materials of GDL-BTCC. In this study, the topic of materials designed was applying derivative algebraic functions. Furthermore, the learning materials that developed were: Lesson Plan (LP), Student Book (SB), Student Worksheet (SW), student Mathematical Problem Solving Ability Test (MPSAT) and student' Mathematical Self-Efficacy Questionnaire (MSEQ).

\section{RESEARCH METHOD}

This research was development research (design research). This study used a model of development of Thiagarajan et al. (1920) which is also often referred to as 4-D. Development research was conducted to obtain learning materials that were valid, practical, and effective (Nieveen \& Folmer, 2013) and improve mathematical problem solving ability and mathematical self-efficacy of students.

The research was conducted at SMA Negeri 1 Pagaran, which is one of the high schools in Pagaran District, North Tapanuli Regency, Indonesia. This demographic condition in Pagaran District is a community with a majority of Batak Toba tribes. The socio-cultural life of the community is still trying to maintain the traditions of the ancestors that are undergoing changes as the development of science, technology and art.

The subjects in this study were class XI IPA (11 ${ }^{\text {th }}$ grade learners') students at SMA 1 Pagaran 2018/2019 academic year, while the objects in this study were learning materials developed based on the GDL-BTCC model on algebraic function derivative topic.

This study analyzed difference mathematical problem solving ability between students who received learning treatment with GDL-BTCC, with students who followed ordinary learning using inferential statistics. The analysis was carried out after obtaining qualified GDL-BTCC; Learning materials that had met valid, practical and effective criteria. The learning outcomes of the last trial class were compared with the learning outcomes of the control group (class that taught with ordinary learning).

With the viewpoint above, the population in this study was Class XI IPA SMA Negeri 1 Pagaran. The sample used as a basis for generalizing is the trial class which was taught by the final materials. At the time of testing the materials, the final materials was obtained during the second trial, which was during the trial in Class XI IPA 3. Thus, the experimental group in this study was class XI IPA 3. The control group, class learned with ordinary learning (class that was not given treatment) was class XI IPA 1.

The trial design used in this study was nonequivalent control group design (Sugiyono, 2017). The research design presented in Table 1.

Table 1. Nonequivalent Control Group Design

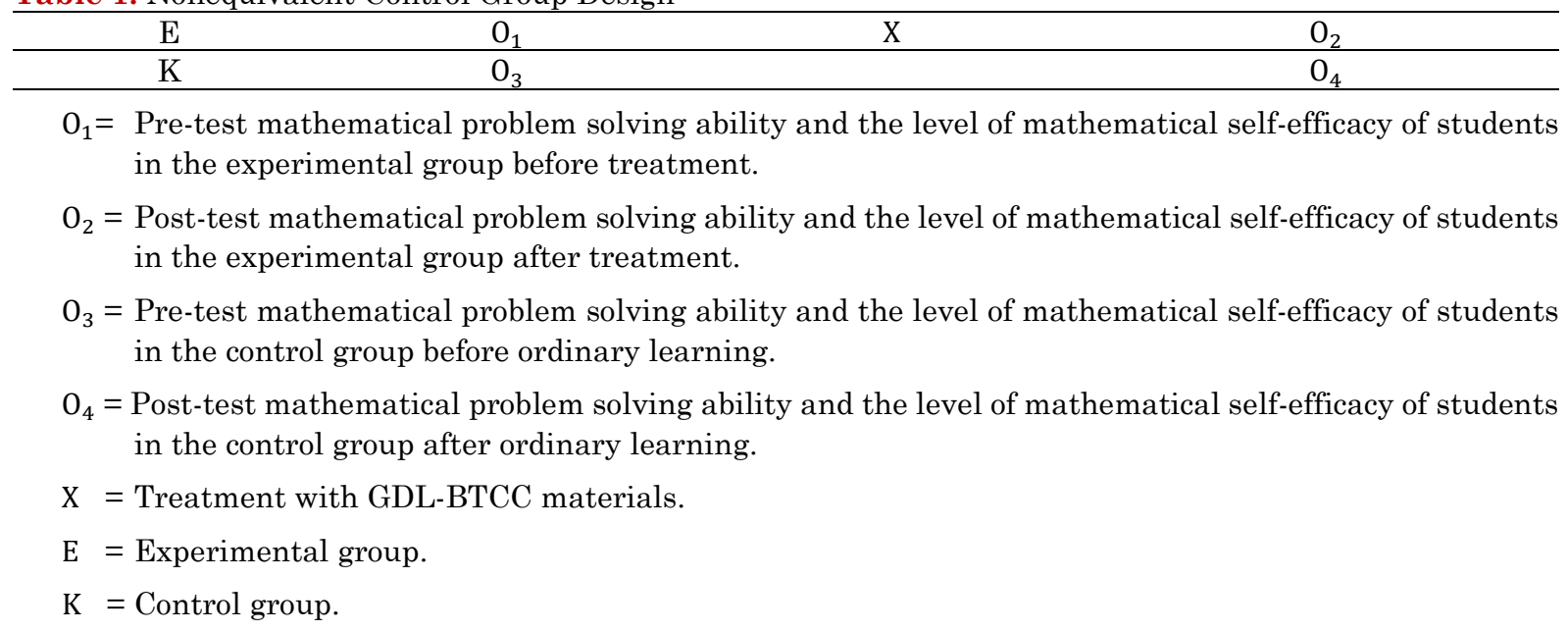

The results of the MPSAT of students from each experimental and control group were tested with mean differences that analyzed with $t$-test. In this case, the researcher did not determine which group's opinion had a higher mathematical problem solving ability before treatment. Which was checked, whether there were 
differences in mathematical problem solving ability as a benchmark to conclude whether there was an increase in students' mathematical problem solving ability significantly when taught with GDL-BTCC. In this case the researcher used a two-tails test at the $95 \%$ confidence level.

Meanwhile, to analyze the increase in students' mathematical self-efficacy beliefs between the experimental group and the control group, it was seen from the increase in self-efficacy before and after learning. The difference in the level of self-efficacy of students before and after learning in the trial class was compared with the difference in the level of self-efficacy of students before and after learning in ordinary learning.

\section{RESULT}

In this developmental research, GDL-BTCC materials had met the criteria of valid, practical and effective in second trial, or in other words, the final draft has been obtained in second trial. In this study, students' problem-solving ability and mathematical self-efficacy learned by using the final GDL-BTCC materials compared to the class taught with ordinary learning.

\section{The Increasing of Students' Mathematical Problem Solving Ability}

To met the requirements for conducting a statistical analysis, checking the normality of the results of the pretest and posttest, both in the control group, and experimental group. Checking the normality of data using Kolmogorov-Smirnov and Shapiro-Wilk using SPSS 20 software and giving results that the pretest and posttest data in the control group and experimental group were normally distributed. Checking the homogeneity of the variance of the pretest of the control group with the experimental group was carried out using the Levene test and gave the results that the pretest of the experimental group with a homogeneous control group or originating from the same population. Through inferential analysis using the t test, it was found that there were no differences in students' mathematical problem solving ability between the experimental group and the control group.

Meanwhile, the results of the experimental group and control group posttest were normally distributed and had a non-homogeneous variance. Because sum of samples of the experimental group and the control group are not the same and the variance was not homogeneous, testing was done with the $t$-test separated variant. The calculation results get the result that the value of $t_{\text {count }}=2.6960$. To make a decision, whether the difference was significant or not, the value of $t_{\text {count }}$ above was consulted with the value of $t$-table on the two-tail test with an error rate of $5 \%$. Obtained $t_{\text {table }}$ value $=2.40$. That meant $t_{\text {count }}>t_{\text {table }}(2.6960>2.40)$. So, it could be concluded that there were significant differences between the posttest results of students' mathematical problem solving ability between the control group and the experimental group. In this study, the posttest of experimental group was better that control group. So, mathematical problem solving ability had increased after learning using the GDL-BTCC materials.

\section{The Increasing of Student's Mathematical Self-Efficacy}

To determine the extent of the influence using GDL-BTCC materials on students' mathematical selfefficacy, the increase of mathematical self-efficacy between the experimental group were compared to the increase the control group. In the control group, learning worked as usual. Before and after the control group studied, students were asked to fill the MSEQ. The results of questionnaire before and after ordinary learning were analyzed using Wilcoxon Matched Pairs using SPSS 20 at the level of $\propto=0.05$. Significance value (Sig.) yields 0.674 . Obtained that $0.674>0.05$. That meant that there was no significant difference in students' selfefficacy beliefs before and after normal learning in the control group.

Meanwhile, results before and after learning using GDL-BTCC materials were also analyzed using Wilcoxon Matched Pairs using SPSS 20 at the level of $\propto=0.05$. Significance value (Sig.) showed 0.030 . Obtained that $0.030<0.05$. That meant that there were significant differences in students' self-efficacy beliefs before and after learning using the GDL-BTCC materials. Thus it could be concluded that there was a significant increase in students' mathematical self-efficacy when students were taught by using the GDLBTCC materials while when students were taught by ordinary learning, there was no increase. 


\section{DISCUSSION}

From the description above, it is found that learning using GDL-BTCC materials improved students' mathematical problem solving ability. The improvement of students' mathematical problem solving ability is inseparable from the guided learning model that form the basis of the GDL-BTCC materials. As said by Bruner (1961) that discovery learning facilitated students' thinking with problem solving skills which could then be transferred to various situations so as to increase intellectual potential would be increased. Meanwhile, the experience of students when solving problems with their small groups with socio-cultural approaches, in accordance with Vygotsky's (1978) thinking, improved higher mental function.

To solve a problem, a problem solver can use the strategy or steps formulated by Polya (1973), namely: first understanding the problem; see clearly what is requested. Second, understand how various things are connected, how the unknown is connected with data, to get ideas about solutions, to plan solutions. Third, implement the plan. Fourth, pay attention to the solutions that have been obtained, review and discuss them. Learning activities using the GDL-BTCC materials in this study included the Polya's problem solving. When learning using GDL-BTCC materials, according to Dewey's idea (1938), students learn by doing through a scientific approach. To improve students' mathematical problem solving ability, students were taught by systematically solving mathematical problems.

According to Alfieri et al., (2011) guidance in the form of feedback, worked examples, scaffolding, and elicited explanations will be very beneficial to students in students' cognitive development. Learning by using the GDL-BTCC materials accommodates these guidance. In problem solving activities, each problem with SW was facilitated by scaffoldings. At each meeting using GDL-BTCC materials, students were asked to display the results of concept discovery or problem solving as examples of work, and the teacher would provided feedback on the presentation. In addition, alternative problem solving was provided in a SB that could be used as an example of work when studying independently. The results of this study were in accordance with the results of the materials development research obtained by Yuliani \& Saragih (2015) which gave results that students' ability to understand concepts and critical thinking mathematically improved when taught with guided discovery learning. The results of this study were also in accordance with the results of the study of In'am \& Hajar (2017) when applying discovery learning with the scientific approach, and the result showed that student learning in geometry may be said very good.

Learning by using GDL-BTCC materials that use the students' local culture was attractive to students. Integration of local culture in mathematics learning also took a role in improving problem solving skills in this study. The results of this study were consistent with the research obtained by Yusra \& Saragih (2016) which stated that culture-based learning, which in this case Malay culture, has a positive influence on mathematics learning. The study found that Joyful Learning with the context of Malay culture could help students discover mathematical concepts independently with the atmosphere that students like. Learning also made students more active in asking questions and has the ability to think more imaginatively and diverse in solving mathematical problems that make students better able to communicate better mathematics. The development of materials that provide results of increasing mathematical problem solving ability was also in accordance with the results obtained by Ritonga et al. (2017). The study stated that the development of learning materials oriented to Model of Eliciting Activities (MEA) succeeded in improving students' mathematical problem solving ability in SMP Negeri 17 Medan.

Bandura $(1994$; 1999) said that there were four main sources of self-efficacy beliefs, namely mastery experiences, vicarious experience, social persuasion, and physical and emotional states. In the context of mathematics learning, the mastery experience of students can be improved when students are guided in solving problems. Problems that were assigned to be solved by students in learning by using GDL-BTCC materials were challenging problems and were within the reach of students' cognitive development. The success of students solving problems would increase students' self-efficacy beliefs (Schunk \& Pajares; 2001). Students' vicarious experience in mathematics learning can be improved by giving students the opportunity to see their friends succeed in solving problems or the teacher explains how other students solve problems (Bonne \& Lawes, 2016). This GDL-BTCC materials accommodated the vicarious experience through presenting the results of problem solving and student discovery.

Interaction between students and teachers in problem solving activities such as scaffolding and presentation of students' work, teachers give feedback and give praise for each student's success (Schunk and Pajares, 2001). Giving feedback is a social persuasion in increasing students' self-efficacy beliefs. The teacher's activities to motivate students through ancestral upbringing in apperception activities also become a part of 
social persuasion. Ancestral education such as: "sude do jolma na malo molo marsisukkunan" (everyone will be smart when doing dialectics). GDL-BTCC materials that facilitated students an comfort atmosphere improved students' emotional states. These things have an effect on increasing the mathematical self-efficacy of students in this study.

The increasing of mathematical self-efficacy in this study was appropriate to other researchs. The development GDL-BTCC materials that use local culture obtained results in accordance with the study of Azwar et al. (2017). The study provided results that the development of learning materials based on the Contextual Teaching Learning Based on the Aceh Cultural Context (CTL-BKBA) based on the first and second trials found that learning materials developed based on the CTL-BKBA model were effective for improving student representation and self-efficacy. In addition, the results of the study were in accordance with the results obtained by Liu \& Koirala (2009) which stated that mathematical self-efficacy towards mathematical achievement among upper-class students in the United States was positively correlated. This study is also in accordance with the results of the research of Ayotola \& Adedeji (2009) and Skaalvik et al. (2015) which obtained results that there was a strong relationship between mathematics learning achievement and selfefficacy.

\section{CONCLUSION}

From the discussion above, it can be concluded that problem solving ability and mathematical self-efficacy of students have increased after learning using the GDL-BTCC materials. This research shows that the integration of local culture in mathematics learning is an important matter to be considered in an effort to maximize students' mathematics learning achievements. Thus, it is expected that mathematics teachers facilitate students learning materials and integrate local culture in mathematics learning at school.

\section{Disclosure statement}

No potential conflict of interest was reported by the authors.

\section{Notes on contributors}

Rustam E. Simamora - State University of Medan, Medan, Indonesia.

Sahat Saragih - State University of Medan, Medan, Indonesia.

Hasratuddin - State University of Medan, Medan, Indonesia.

\section{REFERENCES}

Alfieri, L. Brooks, P. J., Aldrich, N. J., \& Tenenbaum, H. R. (2011). Does Discovery-Based Instruction Enhance Learning?. Journal of Educational Psychology; American Psychological Association, 103(1), 1-18. https://doi.org/10.1037/a0021017.supp

Ayotola, A., \& Adedeji. (2009). The relationship between mathematics self-efficacy and achievement in mathematics. World Conference Education Science; Procedia Social and Behavioral Sciences, 1(2009), 953-957. https://doi.org/10.1016/j.sbspro.2009.01.169

Azwar Surya, E., \& Saragih, S. (2017). Development of Learning Devices Based on Contextual Teaching and Learning Model Based on the Context of Aceh Cultural to Improve Mathematical Representation and Self-efficacy Ability of SMAN 1 Peureulak Students. Journal of Education and Practice, 8(27), 186195.

Bahar, A., \& Maker, C. J. (2015). Cognitive Backgrounds of Problem Solving: A Comparison of Open-ended vs. Closed Mathematics Problems. Eurasia Journal of Mathematics, Science \& Technology Education, 11(6), 1531-1546.

Balamurugan. (2015). Ethnomathematics; An Approach for Learning Mathematics from Multicultural Perspectives. International Journal of Modern Research and Reviews, 3(6). 716-720.

Balım, A. G. (2009). The Effects of Discovery Learning on Students' Success and Inquiry Learning Skills. Eurasian Journal of Educational Research, 35, 1-20. 
Bandura, A. (1994). Self-efficacy. In V. S. Ramachaudran (Ed.), Encyclopedia of humanbehavior (4, 71-81). New York: Academic Press. (Reprinted in H. Friedman (Ed.), Encyclopedia of mental health. San Diego: Academic Press, 1998)

Bandura, A. (1999). A Social Cognitive Theory of Personality. In L. Pervin \& O. John (Ed.), Handbook of personality (2nd ed., pp. 154-196). New York: Guilford Publications.

Bell, F. H. (1981). Teaching and Learning Mathematics (in Secondary School). Lowa: Wm, C. Brown Company.

Bonne, L., \& Lawes, E. (2016). Assessing Students' Maths Self-Efficacy and Achievement. Assessment News, 2, 60-63. https://doi.org/10.18296/set.0048

Bruner, J. S. (1961). The Act of Discovery. Harvard Educational Review, 3(1), 21-32.

d'Ambrosio, U. (2006a). Ethnomathematics Link between Traditions and Modernity. Rotterdam, Netherlands: Sense Publisher.

d'Ambrosio, U. (2006b). The Program Ethnomathematics and the Challenges of Globalization. Circumscribere; International Journal for the History of Science, 1, 74-82.

d'Entremont, Y. (2015). Linking mathematics, Culture and Community. Procedia - Social and Behavioral Sciences, 174(2015), 2818-2824. https://doi.org/10.1016/j.sbspro.2015.01.973

Dewey, J. (1938). Experience \& Education. New York, NY: Kappa Delta Pi.

Ernest, P. (1991). The Philosophy of Mathematics Education. London: Routledge Falmer.

Evans, S., \& Swan, M. (2014). Developing Students' Strategies for Problem Solving. Educational Designer, $2(7), 1-31$.

Foshay, R., \& Kirkley, J. (2003). Principles for Teaching Problem Solving. ---- : Plato Learning.

Haenen, J., Schrijnemakers, H., \& Stufkens, J. (2003). Sociocultural Theory and the Practise of Teaching Historical Concepts. Kozulin, A., Gindis, B., Ageyev, V. S. dan Miller, S. M. (Eds). Vygotsky's Educational Theory in Cultural Context. New York: Cambridge University Press. https://doi.org/10.1017/CB09780511840975.014

Herdiana, Y., Wahyudin, \& Sispiyati, R. (2017). Effectiveness of Discovery Learning Model on Mathematical Problem Solving. AIP Conference Proceedings 1868, 050028(2017), 2-8. https://doi.org/10.1063/1. 4995155

In'am, A., \& Hajar, S. (2017). Learning Geometry through Discovery Learning Using a Scientific Approach. International Journal of Instruction,10(1), 55-70. https://doi.org/10.12973/iji.2017.1014a

Kaiser, G. (2002). Educational Philosophies and Their Influence on Mathematics Education - An Ethnographic Study in English and German Mathematics Classrooms. ZDM, 34(6), 241-257.

Kementerian Pendidikan dan Kebudayaan. (2014). Materi Pelatihan Guru Implementasi Kurikulum 2013 Tahun 2014; Mata Pelajaran Matematika SMA/SMK. __ : Badan Pengembangan Sumber Daya Manusia Pendidikan dan Kebudayaan dan Penjaminan Mutu Pendidikan - Kementerian Pendidikan dan Kebudayaan.

Kuzle, A. (2013). Patterns of Metacognitive Behavior During Mathematics Problem-Solving in a Dynamic Geometry Environment. International Electronic Journal of Mathematics Education - I $\Sigma J M \Sigma, 8(1), 20$ 40.

Learning Theories. (2017). Discovery Learning (Bruner) in Learning Theories. https://www.learningtheories.com/discovery-learning-bruner.html

Liu, X., \& Koirala, H. (2009). The Effect of Mathematics Self-Efficacy on Mathematics Achievement of High School Students. NERA Conference Proceedings 2009, 30. http://digitalcommons.uconn.edu/nera_2009/ 30

Miettinen, R. (2000). The Concept of Experiential Learning and John Dewey's Theory of Reflective Thought and Action. International Journal of Lifelong Education, 19(1), 54-72. https://doi.org/10.1080/ 026013700293458

Motlagh, S. E., Amrai, K., Yazdani, M. J., Abderahim, H. A. \& Souri, H. (2011). The Relationship Between Self-efficacy and Academic achievement inhigh school students. Procedia Social and Behavioral Sciences, 15, 765-768. https://doi.org/10.1016/j.sbspro.2011.03.180

Nasution, T. K., \& Sinaga, B. (2017). Development of Student Worksheet Geometry Based Metacognitive Strategy Through Creative Thinking Ability. IOSR Journal of Research \& Method in Education (IOSRJRME), 7(4), 10-18. https://doi.org/10.9790/7388-0704041018 
NCTM. (2000). Principles and Standards for School Mathematics. Reston, VA: National Council of Teachers of Mathematics (NCTM).

NCTM. (2000). Principles and Standards for school mathematics. Reston, VA: National Council of Teachers of Mathematics.

Nesari, A. J., \& Heidari, M. (2014). The Important Role of Lesson Plan on Educational Achievement of Iranian EFL Teachers' Attitudes. International Journal of Foreign Language Teaching \& Research, 3(5), 2531.

Nidya, Wulandari, F. \& Jailani. (2015). Indonesian Students' Mathematics Problem Solving Skill in PISA And TIMSS. Proceeding of International Conference on Research, Implementation and Education of Mathematics and Sciences 2015 (ICRIEMS 2015), Yogyakarta State University, 17-19 May 2015.

Nieveen, N., \& Folmer, E. (2013). Formative Evaluation in Educational Design Research. Dalam Plomp, T. \& Nieveen, N. 2013. Educational Design Research. Netherland: SLO.

Olayinka, A. R. B. (2016). Effects of Instructional Materials on Secondary Schools Students' Academic Achievement in Social Studies in Ekiti State, Nigeria. World Journal of Education, 6(1), 32-39. https://doi.org/10.5430/wje.v6n1p32

Palhares, P. (2012). Mathematics Education and Ethnomathematics. A Connection in Need of Reinforcement. REDIMAT Journal of Research in Mathematics Education, 1(1), 79-92.

Phonapichat, P., Wongwanich, S. \& Sujiva, S. (2014). An Analysis of Elementary School Students' Difficulties in Mathematical Problem Solving. Procedia - Social and Behavioral Sciences, 116(2014), 3169-317. https://doi.org/10.1016/j.sbspro.2014.01.728

Pintér, K. (2012). On Teaching Mathematical Problem-Solving and Problem Posing. PhD Thesis, University of Szeged, Szeged.

Polya, G. (1973). How to Solve It (2nd ed). Princeton: Princeton University Press.

Ritonga, E. M., Surya, E., \& Syahputra, E. (2017). Development of Learning Devices Oriented Model Eliciting Activities to Improve Mathematical Problem Solving Ability Junior High School Students. International Journal of Sciences: Basic and Applied Research (IJSBAR), 33(3), 42-52.

Rosa, M., \& Orey, D. C. (2016). State of the Art in Ethnomathematics. Rosa (Eds.). Current and Future Perspectives of Ethnomathematics as a Program, ICME-13 Topical Surveys, 11-37. https://doi.org/10.1007/978-3-319-30120-4_3

Saragih, S., \& Napitupulu, E. (2015). Developing Student-Centered Learning Model to Improve High Order Mathematical Thinking Ability. International Education Studies, 8(6), 104-112. https://doi.org/10.5539/ies.v8n6p104

Saragih, S., Napitupulu, E. E., \& Fauzi, A. (2017). Developing Learning Model Based on Local Culture and Instrument for Mathematical Higher Order Thinking Ability. International Education Studies, 10(6), 104-122. https://doi.org/10.5539/ies.v10n6p114

Scherer, R., \& Beckmann, J. F. (2014). The Acquisition of Problem Solving Competence: Evidence from 41 Countries that Math and Science Education Matters. Large-scale Assessments in Education, 2(10), 122. https://doi.org/10.1186/s40536-014-0010-7

Schoenfeld, A. H. (1987). Polya, Problem Solving, and Education. Mathematics Magazine, 60(5), $283-291$.

Schoenfeld, A. H. (2010). Reflections of an Accidental Theorist. https://www.researchgate.net/publication/ 289712738

Schoenfeld, A. H. (2013). Reflections on Problem Solving Theory and Practice. The Mathematics Enthusiast, $10(1,2), 9-32$.

Schoenfeld. A. H. (1980). Teaching Problem-Solving Skills. The American Mathematical Monthly, 87(10), 794805. https://doi.org/10.2307/2320787

Schunk, D. H., \& Pajares, F. (2001). The Development of Academic Self-Efficacy. Bab pada A. Wigfield \& J. Eccles (Eds.) Development of Achievement motivation. San Diego: Academic Press. San Diego: Academic Press.

Shieh, C. J., \& Yu, L. A. (2016). Study on Information Technology Integrated Guided Discovery Instruction toward Students Learning Achievement and Learning Retention. Eurasia Journal of Mathematics, Science \& Technology Education, 12(4), 833-842. https://doi.org/10.12973/eurasia.2015.1554a 
Simamora, R. E., Sidabutar, D. R., \& Surya, E. (2017). Improving Learning Activity and Students' Problem Solving Skill through Problem Based Learning (PBL) In Junior High School. International Journal of Sciences: Basic and Applied Research (IJSBAR), 33(2), 321-331.

Simamora, S. J., Simamora, R. E., \& Sinaga, B. (2017). Application of Problem Based Learning to Increase Students' Problem Solving Ability on Geometry in Class X SMA Negeri 1 Pagaran. International Journal of Sciences: Basic and Applied Research (IJSBAR), 36(2), 234-251.

Skaalvik, E. M., Federici, R. A., \& Klassen, R. M. (2015). Mathematics Achievement and Self-efficacy: Relations with Motivation for Mathematics. International Journal of Educational Research,72, 129136. https://doi.org/10.1016/j.ijer.2015.06.008

Sugiyono. (2017). Metode Penelitian Kuantitatif, Kualitatif dan R \& D. Bandung: Alfabeta

Szetela, W., \& Nicol, C. (1992). Evaluating Problem Solving in Mathematics. Educational Leadership, 5, 4245.

Taylor, L. (1993). Vygotskyan Scientific concepts: Implications for Mathematics Education. Focus on Learning Problems in Mathematics, 15, 2-3.

Thiagarajan, S., Semmel, D. S., \& Semmel, M. I. (1974). Instructional Development for Training Teachers of Exceptional Children. A Sourcebook Indiana: Indiana University

Trianto. (2013). Model Pembelajaran Terpadu dalam Teori dan Praktek. Jakarta: Prestasi Pustaka.

Vygotsky, L. S. (1978). Mind in Society: The Development of the Higher Psychological Processes. Cambridge, MA: The Harvard University Press.

Wheeler, D. D. (1970). Processes in Word Recognition. Cognitive Psychology, 1(1), 59-85. https://doi.org/10.1016/0010-0285(70)90005-8

Yang, E. F. Y., Liao, C. C. Y., Ching, E., Chang, T., \& Chan, T. W. (2010). The Effectiveness of Inductive Discovery Learning in 1: 1 Mathematics Classroom. Proceedings of the 18th International Conference on Computers in Education. Putrajaya, Malaysia: Asia-Pacific Society for Computers in Education, 743747.

Yerizon, Putra, A. A., \& Subhan, M. (2018). Mathematics Learning Instructional Development based on Discovery Learning for Students with Intrapersonal and Interpersonal Intelligence (Preliminary Research Stage). International Electronic Journal of Mathematics Education, 13(3), 97101. https://doi.org/10.12973/iejme/2701

Ylimaki, R. (2010). Towards a Neo-Vygotskian Approach to 21st Century Learning.

Yuliani, K., \& Saragih, S. (2015). The Development of Learning Devices Based Guided Discovery Model to Improve Understanding Concept and Critical Thinking Mathematically Ability of Students at Islamic Junior High School of Medan. Journal of Education and Practice, 6(24), 116-128.

Yusra, D. A., \& Saragih, S. (2016). The Profile of Communication Mathematics and Students' Motivation by Joyful Learning-based Learning Context Malay Culture. British Journal of Education, Society \& Behavioural Science, 15(4), 1-16. https://oi.org/10.9734/BJESBS/2016/25521

Zimmerman, B. J. (2000). Self-Efficacy: An Essential Motive to Learn. Contemporary Educational Psychology, 25, 82-91. https://doi.org/10.1006/ceps.1999.1016 